Дарина СОЛОВЕЙ, orcid.org/0000-0001-6287-4078 аспірантка, викладач кафедри романської і новогрецької філологї та перекладу Київського національного лінгвістичного університету (Kиї, Україна) solovei.dar.alex@gmail.com

\title{
АДАПТАЦІЯ ІТАЛІЙСЬКОМОВНИХ БІБЛІЙНИХ ЄВАНГЕЛЬСЬКИХ ТЕКСТІВ ДЛЯ РІЗНОВІКОВОї АУДИТОРї̈
}

Статтю присвячено виявленню чинників застосування адаптачї̈ у перекладі євангельських текстів італійською мовою для дітей і дорослих. Об'єктом дослідження було обрано явище адаптації у біблійних текстах, а саме Свангеліє від Марка шостого розділу. Було визначено, зокрема, структуру Біблї; проаналізовано дослідження біблеїстів стосовно перекладу Писання; визначено поняття «адаптаџія».

Проведений аналіз позицій зарубіжних і вітчизняних дослідників щзодо явища адаптації уможливив виявлення певних закономірностей у стратегії адаптаиії євангельських текстів різної складності для кращого сприйняття читачем. Проведено аналіз прийомів адаптивних стратегій на прикладах тексту Свангелія від Марка шостого розділу. Проаналізовано дві стратегії адаптаиії за В. В. Демецьькою - адаптацію типу тексту та адаптаичію інформації типу тексту. Проаналізовано дослідження С. В. Іонової щчодо поняття адаптації.

У статті представлено аналіз перекладу італійськомовних євангельських текстів для дітей $і$ дорослих. Було досліджено та проаналізовано історію перекладу Біблії на украӥнську мову ХІХ ст. Проведено аналіз перекладу тексту Свангелія з урахуванням вікової аудиторії. У статті представлено компаративний аналіз одного і того ж послання, але для різної вікової аудиторії.

Досліджено прагматичні характеристики функиії адаптації тексту в перекладах релігійних текстів різних рівнів складності італійською та украӥнською мовами на основі порівняння перекладу текстів Свангелія в мовознавчому і перекладознавчому аспектах. Встановлено, щуо адаптивні перекладацькі стратегії при перекладі біблійних текстів є адекватним підходом до відображення маркованої лексики, оскільки не мени важливим завданням перекладача є збереження головної ідеї Писання.

Ключові слова: біблійні тексти, адаптація, італійська мова, перекладознавство.

Daryna SOLOVEI, orcid.org/0000-0001-6287-4078

Graduate Student, Teaching Assistant at the Department of Romance and Modern Greek Philology and Translation Kyiv National Linguistic University (Kyiv,Ukraine)solovei.dar.alex@gmail.com

\section{ADAPTATION OF ITALIAN-LANGUAGE BIBLE GOSPEL TEXTS FOR A DIVERSE AGE AUDIENCE}

The article is devoted to the identification of factors of adaptation in the translation of gospel texts in Italian for children and adults. The phenomenon of adaptation in biblical texts, namely the Gospel of Mark the Sixth Chapter, was chosen as the object of the study. In particular, the structure of the Bible was determined. Biblical studies regarding the translation of the Scriptures were analyzed. The concept of adaptation was defined.

The analysis of foreign and domestic researchers' positions on the phenomenon of adaptation made it possible to identify certain patterns in the strategy of adaptation of gospel texts of varying complexity for better reader perception. The analysis of adaptive strategies techniques was carried out using examples of the text of the Gospel of Mark the Sixth chapter. Two adaptation strategies by $V$. V. Demetska were analyzed: "Text type adaptation and text type information adaptation". S. V. Ionova's research on the concept of adaptation is analyzed.

The article presents an analysis of translation of Italian-language Evangelical texts for children and adults. The history of translation of the Bible into the Ukrainian language of the XIX century was investigated and analyzed. The analysis of translation of the Gospel text was carried out taking into account the age audience. The article presents comparative analysis of the same message, but for different age audiences.

In addition, pragmatic characteristics of the function of adaptation of the text in the translations of religious texts of different levels of complexity in Italian and Ukrainian languages, namely by comparing the translation of texts of the Gospel in the linguistics and translated aspects, are studied. It was determined that adaptive translation strategies in the translation of biblical texts is an adequate approach to the display of marked vocabulary, since no less important task for the translator is also to preserve the main idea of the Scriptures.

Key words: biblical texts, adaptation, Italian language, translation studies. 
Постановка проблеми. Однією 3 найголовніших цілей перекладача $є$ передача інформації 3 мови оригіналу на мову перекладу 3 найменшим відсотком втрати змісту під час перекладу, що досягається завдяки рівню знань перекладача, а також різноманітним особливостям адресата цього перекладу. Не менш важливою є реалізація перекладу інформації на іноземну мову. Так, у разі усного перекладу інтерпретатор може використовувати міміку обличчя, жести, інтонацію й інші прийоми, які б допомогли йому точно передати необхідний зміст, що унеможливлюється при письмовому перекладі.

Для досягнення високого рівня якостіперекладу обов'язково враховуються певні характеристики адресата: вік, рівень знань у тій чи іншій сфері діяльності, можливі фонові знання. Від сукупності цих та інших факторів залежить успішність точного розуміння перекладеного тексту читачами. Отже, усвідомлення цих факторів і необхідність узгодження 3 ними кінцевого тексту перекладу спонукають перекладача до застосування адаптації. Оскільки нині адаптація є об'єктом дослідження багатьох українських і європейських мовознавців, розвідка методів і підходів щодо аналізу адаптації текстів для читачів різного віку в перекладознавстві є одним з основних завдань.

Аналіз досліджень. Проблеми лінгвокультурних адаптацій постійно перебувають у фокусі уваги сучасних перекладознавців. Питання лінгвокультурних адаптацій в українськомовних та італійськомовних перекладах євангельських текстів начасперед пов'язані з усвідомленням перекладачем мети перекладу, а також мовних і культурних відмінностей оригіналуй перекладу, обраннямпевної стратегії для зменшення перекладацьких втрат.

Проблематику дослідження адаптації релігійних текстів було висвітлено у працях зарубіжних і вітчизняних науковців (С. С. Аверинцев, В. В. Демецька, В. В. Кабакчі, Л. О. Кузьменко, Н. В. Моховиков, М. В. Шиповських, О. С. Шутова). Переклад біблійних текстів сприяв формуванню національних перекладацьких традицій європейських народів, він $є$ релігійним і культурним феноменом водночас (Мороз, 2016), який здійснювався перекладачами із певними корективами 3 огляду на цільового адресата.

С. В. Іонова зазначає, що під адаптованим текстом ми розуміємо вторинний текст, створений для читачів, які з певних причин не можуть зрозуміти текст-джерело В. В. Демецька пропонує дві стратегії адаптації: «Адаптація типу тексту та адаптація інформації типу тексту. Застосування адаптації інформації в культурі перекладу пояснюеться тим, що зміна інформації типу тексту та засобів ї̈ подання зумовлена лінгвокультурними розбіжностями вихідного тексту та тексту перекладу. Адаптація інформації передбачає пріоритетність інформачії типу тексту, що відповідає не так власне перекладу, як авторській редакиії» (Демецька, 2008: 17). Відповідно до цієї думки ми розуміємо, що основним завданням адаптації інформації у перекладі є передача сутності послання тексту з опертям на культуру мови вихідного тексту і тексту перекладу.

Мета статті полягає у виявленні основних стратегій адаптацій та їхніх закономірностей у євангельських текстах для адресатів різного віку. Об'єкт дослідження - явище адаптації у біблійних текстах. Предметом дослідження є прагматичні характеристики функції адаптації тексту в перекладах релігійних текстів різних рівнів складності італійською і українською мовами на основі порівняння перекладу текстів Свангелія в мовознавчому і перекладознавчому аспектах.

Виклад основного матеріалу. Можна стверджувати, що Біблія є однією з найдавніших книг, яка не тільки збереглася, але й є найпопулярнішою книгою на планеті з огляду на переклад i друк. За даними Evangelische Nachrichtenagentur idea тільки за 2014 рік в усіх країнах було розповсюджено 34 млн iї примірників. Без перебільшення можна стверджувати, що того року кожної секунди видавалася щонайменше 1 Біблія (1 рікблизько 31,6 млн секунд). Проте біблеїсти продовжують працювати над вдосконаленням перекладів або ж створюють нові.

Навіщо ж створювати нові переклади Біблії? Чому ж не досить одного варіанту? Богдан Огульчанський - науковий секретар Відкритого православного університету Святої Софії-Премудрості багато років вивчає переклади Святого Письма українською мовою. Він $\epsilon$ автором словника «Нового Завіту». Словник був створений 3 метою тлумачення Біблії, тому що в перекладах потрібна певна системність, існують певні проблеми перекладу Біблії, через що сучасній людині досить складно iï читати. Новий Завіт був написаний грецькою мовою, яка використовувалася для складання важливих документів як офіційна, а також як мова спілкування у Римській імперії. Як стверджують біблеїсти, Євангелія не є записами учнів, які робилися відразу після того, як Христос говорив до них. Тогочасна спільнота характеризується спільнотою усного мовлення, тобто важливо було переповідати, а не записувати біблійні історії, тому поняття і терміни Святого Письма є неоднозначними. 
Якісні переклади Біблії починаються $з$ середини XIX ст. Автором одного з українськомовних перекладів біблійних текстів Нового Завіту та Псалтиря був Пилип Марочевський - поет-романтик, педагог, перекладач. Його переклад було схвалено до друку, але Російська імперія в жодному випадку не могла його видати, тому що почалися гоніння на українську мову. Над класичним перекладом Біблії багато років працювали Пантелеймон Куліш, Іван Пулюй, до цього перекладу долучився Іван Нечуй-Левицький.

Роботу над перекладом Біблії Пантелеймон Куліш розпочав у 1868 році та здійснював протягом 35 років. За своє життя Пантелеймон Куліш переклав весь Новий Завіт, а також кілька книг Старого Завіту. Переклад книг, які не були перекладені, були доручені на опрацювання Івану Нечуй-Левицькому, а перекладацьку роботу над Псалтирем здійснив Іван Пулюй. Вони склали перший друкований переклад Біблії українською мовою (1880 рік). Переклад Куліша у біблеїстиці вважається першим загальним перекладом повної Біблії. Він дав початок перекладацькій традиції на території України на початку XX ст. (Історія перекладів Біблії українською мовою).

Проблема перекладів є постійною і актуальною, адже мова змінюється і інтереси людей також. Постає питання: чому ж Біблію не читають діти? Хоча історії цікаві, повчальні, вони несуть виховну функцію, розділяють добро і зло. Чому дорослі не розуміють тексту Писання? Однією 3 основних причин $\epsilon$ непрозорість, нетранспарентність тексту, який потребував значних розумових зусиль і неабияких когнітивних здібностей. 3 часом перекладачі почали використовувати адаптацію для того, щоб допомогти читачеві різного віку розуміти текст. Так з'явилися сучасні переклади Біблії, дитячі Біблії.

В електронній «Великій українській енциклопедії» наведено таке визначення для поняття адап- тації: «Адаптація тексту - спрощення тексту літературного твору для того, щчоб непідготовлений читач міг легше сприймати та розуміти його зміст; техніка редагування, пов'язана із наближенням авторського оригіналу до інформаиійних запитів иіільової аудиторії» (Велика українська енциклопедія). 3 цього пояснення ми розуміємо, що адаптацію використовують для того, щоб спростити складний для розуміння текст, наприклад, для дитячої аудиторії або ж спростити текст для осіб, які вивчають іноземні мови.

Адаптація - це перетворення інформації з урахуванням культури, традицій мови джерела, які містяться у тексті оригіналу, для тих читачів, для яких вона була частково недоступною у зв'язку 3 їхньою некомпетентністю в певній сфері діяльності. Особливо важливим елементом у здійсненні міжмовної комунікації є розуміння перекладачем не лише граматики, але й володіння знаннями про культуру мови, 3 якої робиться переклад. Від цього залежить адекватність і розуміння адаптованого тексту читачами.

Проаналізуємо перекладений з італійської на українську мову біблійний фрагмент для дітей 3 послання від Марка 6:35-39. Хочемо зазначити, що переклад фрагменту біблійної історії для дитячої аудиторії відрізняється від фрагменту з синодального перекладу (табл. 1).

У порівнюваних фрагментах українською та італійською мовами перекладачі мали намір адаптувати біблійну історію для кращого сприйняття ii дитиною. Автори перекладу надали яскравих барв ще й тим, що лексему 'chiese', яка походить від інфінітива 'chiedere' (запитувати) перекладач передав лексемою «кинув» для надання тексту більш емоційного забарвлення. При перекладі фрази "Mandali via a comprarsi del cibo" / «Bidпусти людей, нехай розійдуться $i$ куплять їжі у навколишніх селах» 3 італійської на українську було додано «навколишні села», тобто викорис-

Таблиця 1

Gesù aveva finito di insegnare. Tutti erano affamati. "Mandali via a comprarsi del cibo", dissero i Suoi discepoli. Gesù voleva, però, mostrare alle persone che potevano aver fiducia in Dio.

"Perché non date voi da mangiare a loro?" chiese Gesù. "Ci vorrebbe un anno di paga per comprare il pane per tutti!" gridarono i discepoli. "Quanto cibo avete?" chiese Gesù.

"C'è qui un ragazzo" disse Andrea, che ha 5 pani e due piccoli pesci". Gesù sorrise. "Perfetto. Dite alla gente di sedersi sull'erba".
Ісус завершив навчати народ на горі. Усі зголодніли. «Відпусти людей, нехай розійдуться і куплять їжі у навколишніх селах», - порадили учні. Проте Ісус хотів навчити людей довіряти Богу.

«Чом би вам не нагодувати їх?» - кинув Ісус своїм учням. «Нам рік доведеться заробляти, щоб нагодувати стількох людей!»- зневірилися вони. «Скільки їжі у вас $€ ? »-$ запитав Ісус.

«Он один хлопчик, - вказав Андрій, - у якого п’ять буханців хліба і дві рибини». Ісус усміхнувся. «От і чудово. А тепер накажіть усім присутнім розміститися на траві». 
35. Essendo già tardi, i suoi discepoli gli si accostarono e gli dissero: "Questo luogo è deserto ed è già tardi;

36. Lasciali andare, affinché vadano per le campagne e per i villaggi dei dintorni e si comprino qualcosa da mangiare".

37. Ma egli rispose loro: "Date loro voi da mangiare". Ed essi a lui: "Andremo noi a comprare del pane per decento denari e daremo loro da mangiare?".

38. Egli domandò loro: "Quanti pani avete? Andate a

vedere". Essi si accertarono e risposero: "Cinque e due pesci".

39. Allora gli comandò loro di farli accomodare tutti a gruppi sull'erba verde.
35. I, як минуло вже часу доволі, підійшли Його учні до Нього та й кажуть: «Це місце безлюдне, а година вже пізня;

36. Відпусти їх, нехай підуть в осади та села близькі і куплять собі чого їсти.

37. Він відповів їм: «Дайте їсти їм ви». Вони ж відказали Йому: «Чи ми маємо піти та хліба купити на двісті динаріїв і дати їм їсти?»

38. Він їх запитав: «Скільки маєте хліба? Ідіть, побачте!» I розізнавши, вони сказали: «П'ять хлібів і дві рибини».

39. І звелів їм усіх на зеленій траві посадити один біля одного. тано граматичну трансформацію додавання лексем на підставі того, що в Біблії дійсно сказано, що їх хотіли відправити до навколишніх селищ. У перекладі поданої фрази перекладач застосував прийом додавання лексем.

Показовим перекладом є речення "Dite alla gente di sedersi sull'erba"/ «А тепер накажіть усім присутнім розміститися на траві». Дослівний переклад було б представлено так: «Скажіть людям сісти на траву». Чому автор перекладу використовує синонім розміститися у перекладі цього речення, адже логічно i доречно його перекласти саме так, як в італійському варіанті. На нашу думку, тут ми спостерігаємо розбіжність у прагматичному аспекті: перекладачі італійського варіанту мали за мету насамперед передати історію в доступній для італійських дітей формі, а українські перекладачі мали намір створити яскравіше враження від біблійної історії у цільового адресата, тому вони використовують граматичну трансформацію i вживають стилістично забарвлену лексику, щоб вплинути на формування відповідних ментальних образів у дитячій уяві.

Розглянемо ще один фрагмент для іншої вікової категорії послання від Марка 6:35-39. Фрагмент взято 3 сучасного перекладу італійської Біблії, а переклад українського фрагменту належить Івану Огієнку (табл. 2).

Порівнюючи переклад Біблії для більш дорослої вікової категорії, можна зазначити, що переклад як італійської мови, так і української перекладений дослівно, без використання граматичних трансформацій, які були використані для перекладу дитячої версії. 36-й вірш 6-го розділу послання від Марка перекладено без опущень, на відміну від фрагменту для дітей: “Lasciali andare, affinché vadano per le campagne e per $i$ villaggi dei dintorni e si comprino qualcosa da mangiare"/ "Bidnусти їх, нехай підуть в осади та села близькі $i$ куплять собі чого їсти». 39-й вірш цього послання також зберіг точний переклад: “Allora gli comandò loro di farli accomodare tutti a gruppi sull'erba verde” / «I звелів їм усіх на зеленій траві посадити один біля одного».

Надання комунікативної рівності різномовним текстам у процесі перекладу супроводжується частими опущеннями, поясненнями i змінами. Перекладачеві доводиться завжди вирішувати, якими саме елементами тексту оригіналу потрібно пожертвувати, щоб зробити можливим повне відтворення інших, які мають більш комунікативне значення частин тексту оригіналу. Процес міжкультурної комунікації вимагає лінгвокультурної адаптації, під якою розуміється «пристосування тексту за допомогою певних процедур до адекватного варіанту». Він повинен бути цілком відповідним, збігатися, бути тотожним «його сприйняттю читачем іншої культури» (Ніконов, 1998).

Процес адаптації при перекладі передбачає, що текст інформації на одній мові повинен сприйматися і передаватися перекладачем на іншу мову, коли «на основі підданого цілеспрямованому (перекладацькому) аналізу первинного тексту створюється вторинний текст, який заміняє первинний в іншому мовному і культурному середовищі. Процес, який характеризується установкою на передачу комунікативного ефекту первинного тексту, частково модифікується відмінностями між двома мовами, двома культурами і двома комунікативними ситуаціями» (Швейцер: 75).

Висновки. Лінгвокультурна адаптація $є$ необхідним творчим складником перекладацького процесу. Поняття «адаптація» - це спосіб збереження прагматичного потенціалу першоджерела й досягнення його комунікативно-рівноцінної й повноправної заміни (Сопилюк, 2012). Оскільки лінгвокультурна адаптація вихідного тексту зумовлена мовними та культурними розбіжностями, вона реалізується за допомогою різних 
адаптивних стратегій: додавань, вилучень, переміщень і замін мовних елементів різного характеру: фонетичного, лексико-семантичного, лексико-граматичного і фразеологічного.

На нашу думку, використання адаптивних перекладацьких стратегій при перекладі біблійних текстів $€$ адекватним підходом до трансляції культурно маркованої лексики, оскільки не менш важливим завданням перекладача $є$ збереження колориту та емоційної насиченості євангельського тексту з усіма нюансами й відтінками не тільки для спрощення їхнього сприйняття читачем, а й для полегшення розуміння ідей Святого Письма, що посилює його внесок у культурний розвиток людства.

\section{СПИСОК ВИКОРИСТАНИХ ДЖЕРЕЛ}

1. Evangelische Nachrichtenagentur idea : веб-сайт. URL: https://www.idea.de/ (дата звернення: 23.11.2020).

2. La Bibbia. Una traduzione accurata e moderna: Post tenebras lux: Società bibblica di Ginevra. 2008. 808 p.

3. Библия детям : веб-сайт. URL: https://www.bible.com/ru/kids (дата звернення: 23.11.2020).

4. Біблія, або Книги Святого Письма Старого й Нового Заповіту. Із мови давньоєврейської й грецької на українську дослівно наново перекладена: Пер. І. Огієнка 1962 року. К. : Українське Біблійне Товариство, 2009. 1151 с.

5. Біблія в перекладі I. Огієнка : веб-сайт. URL: https://bibleonline.ru/bible/ubio/ (дата звернення: 23.11.2020).

6. Богдан Огульчанський. LB.ua : веб-сайт. URL: https://lb.ua/author/1559_bogdan_ogulchanskiy (дата звернення: 14.11.2020).

7. Велика українська енциклопедія : веб-сайт. URL: https://vue.gov.ua/\%D0\%90\%D0\%B4\%D0\%B0\%D0\%BF\%D1 $\% 82 \% \mathrm{D} 0 \% \mathrm{~B} 0 \% \mathrm{D} 1 \% 86 \% \mathrm{D} 1 \% 96 \% \mathrm{D} 1 \% 8 \mathrm{~F} \% \mathrm{D} 1 \% 82 \% \mathrm{D} 0 \% \mathrm{~B} 5 \% \mathrm{D} 0 \% \mathrm{BA} \% \mathrm{D} 1 \% 81 \% \mathrm{D} 1 \% 82 \% \mathrm{D} 1 \% 83$ (дата звернення: 20.10.2020).

8. Демецька В. В. Теорія адаптації у перекладі : автореф. дис. на здобуття наук. ступеня д-ра філол. наук: 10.02 .16$. Київ, 2008. С. 17.

9. Історія перекладів Біблії українською мовою. Церква адвентистів сьомого дня : веб-сайт. URL: https://adventist.ua/news/analytics/istoriya-perevodov-biblii-na-ukrainskom-yazyke/ (дата звернення: 14.11.2020).

10. Мороз Ю. А. Національна традиція біблійних перекладів в Україні. Гілея : Науковий вісник. 2016.

11. Никонов В. М. Некоторые аспекты лингвокультурологических проблем перевода: денотативные и коннотативные параметры. Социокультурные проблемы перевода. Воронеж : Из-во ВГУ. 1998. № 2. С. $32-46$.

12. Переклад Біблії Куліша та Пулюя. Библия онлайн : веб-сайт. URL: https://bible.by/ubkp/ (дата звернення: 15.11.2020).

13. Пилип Морачевський. Національна бібліотека України імені В. I. Вернадського : веб-сайт. URL: http://www.nbuv.gov.ua/node/4464 (дата звернення: 15.11.2020).

14. Сопилюк Н. М. Лінгвокультурна адаптація психологічної прози М. Пруста в українському художньому перекладі : дис. ... канд. філол. наук: 10.02.16 / Південноукр. нац. педагог. ун-т. Одеса, 2012.275 с.

15. Тимошик М. Книга Книг: історія перекладу й видання Святого Письма українською мовою. Ocвiтa. 2000. № 25. С. 4-5.

16. Тимошик М. Книга серед Книг: історія перекладів Святого Письма українською мовою. Берегиня. 2000. № 4. С. 6-18.

17. Швейцер А. Д. Теория перевода: статус, проблемы, аспекты. М. : Наука. 1988.

\section{REFERENCES}

1. Evangelische Nachrichtenagentur idea. [Idea of evangelistic information agency]. Idea. Available. URL: https://www.idea.de/ (Accessed: 23 November 2020) [in German].

2. La Bibbia. Una traduzione accurata e moderna. [The Bibble. Accurate and modern translation]. Post tenebrax lux. Bible society of Geneva; 2008, 808 p. [in Italian].

3. Bibliya detyam. [The Bible for kids]. Available at. URL: https://www.bible.com/ru/kids (Accessed: 23 November 2020) [in Russian].

4. Bibliia abo Knyhy Sviatoho Pysma Staroho i Novoho Zapovitu. Iz movy davnoyevreiskoi i hretskoi na ukrainsku doslivno nanovo perekladena: per. I. Ohienka 1962. [The Bible or the Holly Scriptures of the Old and New Testaments. Literally re-translated from Hebrew and Greek into Ukrainian: Trans. I. Ohienko 1962]. Kyiv : Ukrainian Bible Society, 2009. 1151 p. [in Ukrainian].

5. Bibliia v perekladi I. Ohienko. [The Bible translated by I. Ohienko]. Available at. URL: https://bibleonline.ru/bible/ ubio/ (Accessed: 23 November 2020) [in Ukrainian].

6. Bohdan Ohulchanskii. LB.ua. Available at. URL: https://lb.ua/author/1559_bogdan_ogulchanskiy (Accessed: 14 November 2020) [in Ukrainian].

7. Velyka ukrainska entsyklopedia. [The great Ukrainian encyclopaedia]. Available at. URL: https://vue.gov.ua/ $\%$ D0\%90\%D0\%B4\%D0\%B0\%D0\%BF\% D1\%82\%D0\%B0\%D1\%86\%D1\%96\%D1\%8F_\%D1\%82\%D0\%B5\%D0\%BA\% D1\%81\%D1\%82\%D1\%83 (Accessed: 20 October 2020) [in Ukrainian].

8. Demetska V. V. Teoriia adaptatsii v perekladi. [The theory of adaptation in translation]. Published summary of dissertation of dr. philology. 10.02.16. Kyiv, 2008. p. 17 [in Ukrainian].

9. Istoriia perekladiv Biblii ukrainskoiu movoiu. [The history Bible's translations in Ukrainian]. The church of the seventhday Adventists. Available at. URL: https://adventist.ua/news/analytics/istoriya-perevodov-biblii-na-ukrainskom-yazyke/ (Accessed: 14 November 2020) [in Ukrainian]. 
10. Moroz Yu. A. Natsionalna tradytsiia bibliinykh perekladiv v Ukraini. [National tradition of biblical translation in Ukraine]. Hileia : Scientific herald, 2016 [in Ukrainian].

11. Nikonov V. M. Nekotorye aspekty lingvokulturologicheskich problem perevoda denotativnye i konnotativnye parametry: Sotsiokulturnye problem perevoda. [Some aspects of linguistic and cultural translation problems denotation and connotation parameters: Sociocultural translation problems]. Voronezh : State university of Voronezh, 1998, № 2, p. 32-46 [in Russian].

12. Pereklad Biblii Kulisha ta Puliuia. Bibliia onlain. [Kulish and Puliuia's translation of the Bible. Online Bible]. Available at. URL: https://bible.by/ubkp/ (Accessed: 15 November 2020) [in Ukrainian].

13. Pylyp Marochevskii. National Library of Ukraine maned after V. I. Vernadskii. Available at. URL: http://www.nbuv.gov.ua/node/4464 (Accessed: 15 November 2020) [in Ukrainian].

14. Sopyluk N. M. Linhvokulturna adaptatsiia psykholohichnoi prosy M. Prusta v ukrainskomu khudozhnomu perekladi. [Lingvocultural adaptation of M. Proust's phychological prose in Ukrainian literary translation]. Dissertation of candidate of Philological Sciences. 10.02.16. South Ukrainian National Pedagogical University. Odesa, 2012 , 270 p. [in Ukrainian].

15. Tymoshik M. Knyha Knyh: Istoria perekladu i vydannia Sviatoho Pysma ukrainskoiu movoiu. [The Book of books: The history of translation and edition of the Holly Scripture in Ukrainian]. Education; 2000, № 25, p. 4-5 [in Ukrainian].

16. Tymoshik M. Knyha sered Knyh: Istoria perekladiv Sviatoho Pysma ukrainskoiu movoiu. [The Book between books: The history of translations of the Holly Scripture in Ukrainian]. Berehynia, 2000, № 4, p. 6-18 [in Ukrainian].

17. Shveitser A. D. Teoriya perevoda: Status, problemy, aspekty. [The theory of translation: Status, problems, aspects]. Moscow : Education; 1988 [in Russian]. 